\title{
Coronavirus and the Ideological, Moral and Metaphysical Challenges to Capitalism, Individual Freedom and Money
}

\author{
Munir A. Abbasi ${ }^{1}$, Azlan Amran ${ }^{1}$, Ibrahim Noorani ${ }^{2}$, Khurram Shakir ${ }^{2}$, Noor e Sahar ${ }^{2} \&$ Nazia Abul Rehman ${ }^{2}$ \\ ${ }^{1}$ Graduate School of Business, Universiti Sains Malaysia (USM), Penang, Malaysia \\ ${ }^{2}$ Benazir School of Business, Benazir Bhutto Shaheed University, Karachi, Pakistan \\ Correspondence: Munir A. Abbasi. Graduate School of Business, Universiti Sains Malaysia (USM), 11800, \\ Penang, Malaysia. E-mail: munyeer@yahoo.com
}

\author{
Received: April 15, $2020 \quad$ Accepted: May 27, $2020 \quad$ Online Published: June 17, 2020 \\ doi:10.5539/ass.v16n7p39 URL: https://doi.org/10.5539/ass.v16n7p39
}

\begin{abstract}
Coronavirus Pandemic has taken the world by storm. Just as it has posited a severe threat to human lives, so has it leveled grave concerns to the mode of life cultured by the world's industrialized societies. Through argumentative analysis, the present study attempts to substantiate that at-least three imminent philosophical crises have arisen in the wake of COVID-19 i.e., ideological, moral, and metaphysical. On the one side, Capitalism and the Free Market have essentially been left defenseless, and individual freedom has substantially been threatened. On the other side, family and social capital have been inflexed with a breath of fresh air.
\end{abstract}

Keywords: coronavirus, capitalism, free market, individual freedom, family, money

\section{Introduction}

Coronavirus, in its entirety, has put the global economic system on the verge of collapse. The notion that capitalism and its corresponding institutions are more efficient than the state, seems to be challenged, as trillions of dollars have been wiped out from the money markets and current economic situation has unwillingly called for the support of states to intervene for a bailout (Aristizábal, 2020). Notwithstanding, it was the requirement for the defenders of the laissez-faire economy, that state must not interfere with the mechanisms of the market (Feldman, 1991) however, as a reversal of fortune, we are witnessing a whole different era, where states are once again required to step in to rescue the markets.

Almost all the European states are condemning the Free Market economy and have realized that system to be a disaster. Governments are looking to nationalize, not only the health sector but also other primary industries, to secure economic prosperity. Spain has nationalized its entire healthcare industry, Italy has nationalized its airline industry (Payne, 2020); Germany and Sweden have announced a bailout package for over $\$ 200$ billion for its private sector. And so is the United States, France, and the UK, as Charles Riley of the CNN puts it, writing blank cheques to save their economies from this deadly pandemic. Serious state intervention has taken place to delimit capital flight, and so derivative markets and stock markets have been frozen to salvage the economic downfall.

Initially, countries in the west, with their free media, vituperated China, for its totalitarian handling to curb the virus. At first, Chinese people were not happy, and around 1.5 million people shared Dr. Wenliang's video, in which he first reported that the corona virus had gone a viral pandemic. They blamed the Chinese government for not taking adequate measures to guarantee the wellbeing of their citizens and criticized their detention of virus-infected individuals and imprisonment of the doctors who spoke against the government for not adopting suitable measures.

Desperate times called for desperate measures, and the authoritarian Chinese rule came into play. A radical transformation took place, as the central government took control of this situation. Six top government officials were sacked on account of negligence, and over three hundred government officials were penalized. In order to manage the crisis, the central government mobilized people's liberation army and all the state's resources. It established two new hospitals in ten days, with each hospital having a capacity of two thousand beds. They set up hotels and gymnasiums as temporary quarantines. Medical health workers roamed on a door to door basis, and if anyone was found with the symptoms of the virus, such individuals were effectively transported to the 
quarantine centers (Sullivan, 2020; Emewu, 2020).

Meanwhile, the state took good care of these patients, provided them with adequate amenities, and isolated them for days to cure them. The state provided them with all the necessary life facilities, and even the patients with mild corona symptoms were provided with adequate medical attention. Because they treated the affected patients in isolation from the population, this strategy worked and gradually corona was defeated in China (Huang et al., 2020)

Contrary to the Chinese economy, where the government has substantial control over the country's economic resources when the same pandemic spread across Europe and the United States, their governments could not control the situation with similar effectivity. This was in part because these countries depend upon the private sector to run their economies. Europe and the United States delved into deep economic crises because fear compelled investors to pull back from the financial markets (Lee, 2020). The sales of guns in the United States have risen during this period, merely out of insecurities, just in case there comes about a shortage of essential life resources (Freeman, 2020).

The American government had to enforce, Defense Production Act 1950, which required businesses, pharmaceutical companies, and healthcare providers to fulfill orders deemed necessary for public defense and produce only supplies that help combat the coronavirus. Huge stimulus packages have been announced to bail out banks and other private companies \& institutions. This is coming from a place where nationalization is considered to be a virus in itself.

\section{Ideological Crisis for Capitalism and the Free Market}

Coronavirus, accidentally segued into an ideological crisis for the defenders of capitalism. For centuries, they have persistently tried to persuade the world how the free market socio-economic structure is better and more efficient than any planned authoritarian economy. However, to their dismay, ironically, the system which is deemed totalitarian, was able to save the lives of thousands of people effectively. In contrast, the laissez-faire markets are unable to respond amply in the wake of such a red alert. This poses a genuine crisis for the justification of the capitalist economy.

Nonetheless, it is a historical fact, that whenever global capital is threatened, it has always been the state which comes to its rescue. From Roosevelt's announcement of the New Deal to inoculate against the Great Depression, to the implementation of demand management and welfare state structures after the world war, states served as the lifeboat to the drowning capitalistic structures (Dighe, 2011). Even after the fall of USSR in 1989, when globalization, free-market economy and neo-liberalism were on the rise, and so was inequality along with it, those fed up with the neoliberalism, observed the failure of capitalist economies and saw that whenever capitalism is in crises, states had to step in to extricate markets, it corresponding billionaires and laissez-faire ideology (Friedman, 2009).

Hence, two very significant contemporary shifts have been witnessed as a consequence of coronavirus. On the one side, there is the Chinese success story of defeating coronavirus with its high profile totalitarian rule, and on the other side, capitalism's cry for help to the state is being heard far and wide. The capitalist economies of the world are calling for state interventions instead of markets to combat this pandemic.

From this, arguments against the supremacy of the free market economy can be drawn, and serious questions are raised upon the efficiency principle these markets adhere to. Coronavirus has given birth to another political, economic, and social threat for Capitalism. Furthermore, despite all its dynamicity, a free-market economy, while fighting for its survival, cannot meet the challenge of this level. Thus, the legitimacy of Capitalism as the global rule is gravely endangered, and a philosophical crisis has developed for its vanguards.

\section{Moral Crises for the Liberals}

Markets, which have colonized the private lifestyles of individuals for years now, are experiencing a downward trend in contrast to an ever-increasing role of the states in the lives of its citizens. This opens up a whole new debate, as to what is to become of individual freedoms. State and individual freedom have been viewed under liberalism as having an antagonistic relationship, and if the governments keep intervening from all ends, then this jeopardized the whole liberal framework.

Philosophers have dichotomized anthropocentricity into two schools of thought; individualism and collectivism. Liberalism is the spearhead of individualism and calls for a society where individual freedom ultimate human value. Whereas for the collectivists, social needs are to be preferred over individual freedom. This goes back to Plato, who writes in his Republic, that a republic should be structured in such a way so that the most rational individuals are ruling over the state. Moreover, Aristotle's definition of a man being a political animal suggests 
that humans can only actualize their full potential when they participate in a communitarian and political life (Barker, 2012). Also, modernist, like Hagel, argues that human is a product of a collective effort and is a member of a community whose spirit is embodied in the structures of the state (Pelczynski, 1984). Fascists philosophies also advocated national identity that lies within the bounds of a powerful state (Schlesinger, 1987), then, of course, Marxism calls for the superiority of a socialist state in order to be free from the capitalist exploitation, and for that establishment of a proletariat socialist state is inevitable (Marx \& Engels, 2002).

Liberals consider this collectivism synonymous with totalitarianism i.e., a despotic rule of law that encroaches in all areas of life and threat democratic values. Early liberal philosophers promoted that humans were most free and had the most basic rights when there was no state. Contractarians like Hobbes, Locke, and Rousseau consider the state of being a product of social contract amongst individuals. For Hobbes, it was under the state of nature that humans had the most liberty. However, the problem with this state of nature was that individuals engaged in a constant battle to fight for their survival and resources, which made life solitary, brutish, limited, and nasty. So, individuals traded some of their freedom to the state and established a sovereign. John Locke also championed for a tacit consent to the law to guarantee the protection of life, property, and liberty (Rapaczynski, 2019).

Rousseau suggests that humans, when deviated from nature, established private property, which resulted in a sovereign state and destroyed our human nature and corrupted ourselves. He proposed General Will as the solution to civilization's problems, i.e., individuals should opt for a general will and become the authors of the modern state, which function as per the will of the people, and ultimately restore natural liberty into a modern society. Immanuel Kant also suggested that to protect the citizens' life and property, the state's power needs to be controlled to a certain extent and limited through an arbitrary exercise to bring about the rule of law (Rousseau, 2018).

This is echoed in the notions of neo-modernists such as Hayek, Mises, Nozek, etc. whom all deem state of being an imposition and a road to serfdom. Even the post-modernist like Foucault, Derrida, and Butler suggests that the state is nothing but an illusion to trap individuals and humans will only be free when there is no state (Dunn, 1997). In short, the Individualistic form of anthropocentricity means you are free to maximize freedom in your individual capacity; we were most free when there was no state. Thus, the liberal thought, in general, does not accept a powerful state and only allow a minimum night-watch role to play.

However, a different take on liberalism is contended by Domineco Losurdo, who argues that instead of heading towards the markets, it is always the State to whom the deprived and oppressed factions of the society turn to for salvation. People have always approached the State to guaranteed their fundamental rights. Politics of rights and all related freedom movements are directed towards the State. It is deemed the responsibility of the State to protect individuals from being exploited by the hands of society's most powerful entities. When these oppressed factions of the society march towards the state for justice, many at times, it compels the State to rule in their favor; which is ironic because very often, the state comprises of those very powerful individuals against whom these oppressed individuals are petitioning (Losurdo, 2014).

This suggests that the State's point of view is limited to a minority of capitalist interests, but has to decide in the collective interests of the entire society. This even calls for decision-making that goes against the interests of the ruling elite and is for the creation of social harmony, so that businesses can function and the system can carry-on. For example, abolitionist movements, which spawned from within Christianity, presented their demands in front of the state to pass a law to ban slavery. Chartists also called upon the state for the right to vote for the labor class and for the abolishment of the property qualification for becoming a member of the Parliament. Similarly, labor movements have also resorted to the state to compel capitalist in restricting work to 8 hours per day (Goodman, 1998). The American Civil Rights Movement by African Americans against the Jim Crow laws, racial segregation, and Ku Klux Klan was also a demand for fundamental human rights made before the State. 1960's feminist movements for equal pay for equal work was another example petitioned before the state to implement and guarantee equal pay and to punish any gender discrimination (Bobo, Kluegel \& Smith, 1997). On the contrary, colonialism in South Asia came about due to company rule by the British, French, and Dutch East India Companies. They looted and polluted their colonies, and natural famine was exacerbated as a result of their loot, thousands of people were killed in the name of trade and commerce (Ty \& Wilson, 2013).

Time and again, socialists like Berny Sanders and Jeremy Corbin, who have long been proponents of the right to equal education and healthcare for all, appealed to the state to compel private colleges and hospitals to guarantee education and healthcare. The state is invoked for the development of laws in order to protect fundamental human rights. Appeals have been made before welfare states to tax the rich and tax cuts for the poor highly. Now, 
if the state agrees to these demands and deems it beneficial for the overall society, it strives to meet the suppressed factions. The state stops the Ku Klux Klan from harming black Americans, or ceases slaveholders from legitimizing serfdom, or compels mill and factory owners to cut down the working hours and implement labor laws, or give women the right to vote and right to equal pay for equal work, education, and healthcare, etc. For this, it is usually the have ones of the society which are heavily taxed and compromised in order for the state to accomplish these things for the oppressed. In turn, that every section of the society calls the state to be an oppressor of individual freedom (Panitch \& Gindin, 2020).

Because they have always been robust, and when the state shows more power over their activities, they feel that our liberty has been threatened by the state, and therefore, the state must not be allowed to meddle into our affairs. Moreover, they feel that the state is suppressing their human rights, freedom, and property right. They do not feel the same way only in one case when the state is empowering the military to conquer some other territories, so ultimately, they can expand their span of freedom.

Now, the Chinese do not accept this liberal discourse. They are oblivious to the notions of Collectivism and Individualism. Even before the communist revolution of 1949, liberalism was never able to gain a stronghold in China. So, Chinese political philosophy holds no inherent dichotomy or contradiction between state and individual freedom (Fung, 2008). On the other hand, in Europe and America, where the state is becoming ever more powerful on account of the corona, liberals are faced with a moral crisis. They are worried that the state's lockdown of the free market is an attempt to curb individual freedoms.

So, corona poses this question: In order to guard against this pandemic, markets are not adequately equipped and cannot help; instead it is only the state which can guarantee protection against it. Furthermore, since the power balance has shifted from the markets to the state, the liberals around the world are challenged in their fundamental beliefs. The role of the state is seen as more important, crucial, and influential throughout the world. Without a free market, hopes for individual freedom seems to have been crushed. Hence, Plato once again emerges as the front runner of political philosophy, and the proper development of the state becomes essential in nurturing a good life for human beings (Cherry, 2012).

\section{Metaphysical Crises for Money and Revival of Family Supremacy}

A textbook definition of money is to be anything that can serve three primary functions: serving as a medium of exchange, as a unit of account and as a store of value (Mishkin, 1992). However, Money, in any form, tend to perform another significant function. That is, money has an inherent ability to isolate, separate, or segregate. For anything which is tainted by money in any of its forms tends to develop the capacity to separate and isolate.

Technology, for instance, is highly capital intensive and requires continuous infiltration of money for its sustenance. The more technology is used, the more money is required to afford and maintain it. Since it has money involved, all such technology tends to separate us from our existing environments. For example, air-conditioning propels closing doors and cut off from the outside world; mobile phones and digital technology uproots its users from the real world and develop a whole separate virtual reality of their own. Likewise, ever since the inception of home appliances such as refrigerators, microwaves and washing machines, humans have compromised altruistic virtues of giving and patience and have developed greed and gluttony instead. We are consuming things that we do not need more and more for our selves and are hesitant to include the less fortunate.

Similarly, people with ever more money tend to develop separatist lifestyles. Their marketplaces are separate from the commoners (for many it is virtual these days); their hangout destinations are exclusive; their education institutions are privileged, and their houses are big enough to afford separate rooms. Hence, anything that money touches can ultimately develop the capacity to separate, isolate, and segregate from the general.

Moreover, the icing on the cake is that the capitalist system is designed in such a way so that in order to earn this money, you have to be separated from your home and family either physically or virtually. Ciscel and Heath (2001) state that market-driven activities have compelled family members to increase their labor market commitments and transform home and family interactions into continuous individual struggles for economic stability.

Discrete altruistic activities such as caring for all family members, food preparation, nursing for sick, disabled, children and elderly, have all been outsourced to the service industry, and the burden of responsibility has been shifted upon the market. And markets successfully afforded isolation to individuals from familial responsibilities, community engagements, and societal cohesion. Since the personal life of the family is being subsumed by the market, and the goal of markets is accumulation, thus money in all its modern forms, also serve to isolate and separate individuals from their natural habitats. 
Modern markets were able to transform almost all human interactions in transient market exchanges (Ciscel \& Heath, 2001). As a counterforce to natural familial relationships, civil societies served as associations of individuals held together by impersonal bonds of interest. These social associations thrive upon the markets for their sustenance. Association Members are required to regularly payout a monetary contribution to maintaining their memberships. This artificially caters to the belongingness needs of individuals that were earlier satisfied by the family, without actually taking on any emotional burden that otherwise would usually come from natural relationships.

Meanwhile, economies around the world are experiencing a slowdown as travel bans are implemented; outings, clubbing, pubbing, shopping and all other forms of artificial social connectivities are being dismantled, and a sharp fall in consumerism has called for a stagnating; henceforth, the new peril to the free markets also levels grave concerns for the artificial connectivities they helped to generate over time (Binder, 2020).

For many, life's meaningfulness and purposefulness came from serving the market and cultivation of professional identities. Their definition of self comes from their market identities, which, when shattered, can resort to acute self-esteem issues. They sacrificed family engagements for market-driven alternatives. Now, when people have to stay at home forcefully, it has become quite a challenge, because there is no worthwhile motive to stay at home. Celebrities, Politicians, Sports-personalities, etc. are coming up with creative solutions to learning to stay at home until the pandemic settles. Thus, this provides a pabulum of reflection upon the emptiness of our daily lives, that came about as a result of market societies (Novel, 2020).

With this corona outbreak, a reversal is observed, as COVID-19 has dramatically altered the global lifestyle. People, being self-isolated and confined to their homes, pushing themselves every day to figure out something worthwhile to do when there is no market activity left. Marx and Engels (1998), had long predicted that under capitalism 'Money Relation' will direct 'Family Relations.' As these market relations are facing somber threats in the wake of coronavirus, the precedence of family and revival of social capital is occasioned.

Family, which was deemed to be the biggest hurdle in the way of capitalism, has come about to be the greatest need of the hour. Family activities create a culture of altruism, obligation, and cooperation. Cultivates an atmosphere of love and care, which ultimately strengthens the bonds of happiness. As opposed to the markets which operate on efficiency principle, the family provides a safe, healthy, and non-competitive environment, which in turn becomes a source for harnessing much-needed self-esteem.

Even though Coronavirus has forced individuals into self-isolation in most parts of the world, on the other hand, it has also provided means to rejuvenate the long-lost social capital that relied on human relationships, social trust, and familial stability and counter what money has done to these natural collectivities.

\section{Conclusion}

The arguments put forth above present capitalism and its corresponding market structures with a minimum of three existential crises. China's successful coup against COVID-19 insinuates that in the face of horrendous catastrophes, it is the State that is most effective in securing its citizens' livelihood concerning the market. The other ideological crisis that emerged in lieu of this pandemic is for the liberals. The aftermath of Coronavirus seemingly restricts individual freedoms, compromising the right to self-determination. Lastly, Coronavirus has inadvertently contributed towards the restoration of family and social capital, which had been deeply contaminated by money and markets at a subtler level.

\section{References}

Aristizábal, D. B. (March 1, 2020). The economic impact of Coronavirus outbreak deepens. Retrieved from www.doralfamilyjournal.com/the-economic-impact-of-Coronavirus-Outbreak-Deepens

Barker, E. (2012). The political thought of Plato and Aristotle. Courier Corporation.

Binder, C. (2020). Coronavirus Fears and Macroeconomic Expectations. https://doi.org/10.2139/ssrn.3550858

Bobo, L., Kluegel, J. R., \& Smith, R. A. (1997). Laissez-faire racism: The crystallization of a kinder, gentler, antiblack ideology. Racial attitudes in the 1990s: Continuity and Change, 15, 23-25. Retrieved from https://scholar.har-vard.edu/files/bobo/files/laissez-faire.pdf

Charles, R. (Mar 17, 2020). CNN Business. Retrieved from www.gwinnettdailypost.com/local/business

Cherry, K. M. (2012). Plato, Aristotle, and the Purpose of Politics. Cambridge University Press. Retrieved from https://scholarship.richmond.edu/cgi/viewcontent.cgi?referer=https://scholar.google.com/\&httpsredir=1\&art icle $=1149 \&$ context $=$ bookshelf 
Ciscel, D. H., \& Heath, J. A. (2001). To market, to market: imperial capitalism's destruction of social capital and the family. Review of Radical Political Economics, 33(4), 401-414. https://doi.org/10.1177/048661340103300403

Dighe, R. S. (2011). Saving Private Capitalism: The US Bank Holiday of 1933. Essays in Economic \& Business History, 29.

Dunn, R. G. (1997). Self, identity, and difference: Mead and the poststructuralists. The Sociological Quarterly, 38(4), 687-705. https://doi.org/10.1111/j.1533-8525.1997.tb00760.x

Emewu, I. (16 March 2020). China and the War against Coronavirus. The Sun. Retrieved from www.sunnewsonline.com/china-and-the-war-against

Feldman, A. M. (1991). Welfare economics. In The World of Economics (pp. 713-726). Palgrave Macmillan, London. https://doi.org/10.1007/978-1-349-21315-3_99

Freeman, B. (Online Tuesday, 17 March 2020 10:40 AM). Gun Sales Up in US During Coronavirus Crisis. Newsmax. Retrieved from www.newsmax.com/newsfront/gun-purchases

Friedman, M. (2009). Capitalism and freedom. University of Chicago press. ISBN 0-226-26421-1.

Fung, E. S. (2008). Were Chinese liberals liberal? Reflections on the understanding of liberalism in modern China. Pacific Affairs, 81(4), 557-576. https://doi.org/10.5509/2008814557

Goodman, P. (1998). Of one blood: Abolitionism and the origins of racial equality. University of California Press.

Huang, C., Wang, Y., Li, X., Ren, L., Zhao, J., Hu, Y., ... \& Cheng, Z. (2020). Clinical features of patients infected with 2019 novel coronavirus in Wuhan, China. The Lancet, 395(10223), 497-506. https://doi.org/10.1016/S0140-6736 (20) 30183-5

Lee, N. Y. (Published online March 11, 2020). 6 charts show the coronavirus impact on the global economy and markets so far. The World Economy. Retrieved from www.cnbc.com/2020/03/12/coronavirus-impact-on

Li, W. L. (Feb 6, 2020). USA Today. Retrieved from www.usatoday.com/story/news/world/2020/02/06

Losurdo, D. (2014). Liberalism: A counter-history. Verso Trade.

Marx, K., \& Engels, F. (1998). Marx \& Engels Collected Works Vol 37: Karl Marx Capital: Volume 3.

Marx, K., \& Engels, F. (2002). The communist manifesto. Penguin. Retrieved from https://www.marxists.org/archive/ marx/works/download/pdf/Manifesto.pdf

Mishkin, F. S. (1992). Anatomy of a financial crisis. Journal of evolutionary Economics, 2(2), 115-130. https://doi.org/10.1007/BF01193536

Novel, C. P. E. R. E. (2020). The epidemiological characteristics of an outbreak of 2019 novel coronavirus diseases (COVID-19) in China. Zhonghua liu xing bing xue za zhi= Zhonghua liuxingbingxue zazhi, 41(2), 145. https://doi.org/10.3760/cma.j.issn.0254-6450.2020.02.003

Panitch, L., \& Gindin, S. (2020). The Socialist Challenge Today: Syriza, Corbyn, Sanders. Haymarket Books.

Payne, A. (March 16, 2020). Spain has nationalized all of his private Hospitals as the country goes into Coronavirus lockdown. Retrieved from www.businessinsider.com/coronavirus-spain

Pelczynski, Z. A. (1984). Political community and individual freedom in Hegel's philosophy of state. The State and Civil Society: studies in Hegel's political philosophy, 55-76. Retrieved from https://www.marxists.org/reference/subject/philosophy/works/ot/pelczyns.htm

Rapaczynski, A. (2019). Nature and politics: Liberalism in the philosophies of Hobbes, Locke, and Rousseau. Cornell University Press.

Rousseau, J. J. (2018). Rousseau: The Social Contract and other later political writings. Cambridge Univ. Press. Retrieved from http://assets.cambridge.org/97805214/13824/frontmatter/9780521413824_frontmatter.pdf

Schlesinger, P. (1987). On national identity: Some conceptions and misconceptions criticized. Information International Social Science Council), 26(2), 219-264. https://doi.org/10.1177/053901887026002001

Sullivan, M. (February 11, 2020). Coronavirus and China's Decision- making in Crisies. The Diplomat. Retrieved from https:/thediplomat.com/2020/02/coronavirus-and-chinas-decision-making-in-a-crisis/

The Defense Production Act of 1950: History, Authorities, and Considerations for Congress. (Updated March 2, 
2020). Congressional Research Service. Retrieved from https://fas.org/sgp/crs/natsec/R43767.pdf

Ty, R., \& Wilson, C. (2013). Colonialism and Nationalism in South East Asia. Retrieved from http://www.seasite.niu.edu/crossroads/ty/COLONIALISM_\%20IN_SE\%20ASIA.htm

\section{Copyrights}

Copyright for this article is retained by the author(s), with first publication rights granted to the journal.

This is an open-access article distributed under the terms and conditions of the Creative Commons Attribution license (http://creativecommons.org/licenses/by/4.0/). 